CURSO DE ESPECIALIZAÇÃO EM DESENVOLVIMENTO HUMANO, EDUCAÇÃO E INCLUSÃO ESCOLAR - UAB/UnB

\title{
O IMPACTO DA DEFICIÊNCIA AUDITIVA SOBRE A FAMÍLIA
}

\author{
Maria do Carmo Conti Vaz de Oliveira
}

ORIENTADORA: VALÍCIA FERREIRA GOMES 
MARIA DO CARMO CONTI VAZ DE OLIVEIRA

\title{
O IMPACTO DA DEFICIÊNCIA AUDITIVA SOBRE A FAMÍLIA
}

\author{
Monografia apresentada ao Curso de Especialização em \\ Desenvolvimento Humano, Educação e Inclusão Escolar, do \\ Depto. de Psicologia Escolar e do Desenvolvimento \\ Humano - PED/IP - UAB/UnB
}

Orientador (a): Valícia Ferreira Gomes 
TERMO DE APROVAÇÃO

MARIA DO CARMO CONTI VAZ DE OLIVEIRA

O IMPACTO DA DEFICIÊNCIA AUDITIVA SOBRE A FAMÍLIA

ORIENTADORA: VALÍCIA FERREIRA GOMES

EXAMINADORA: LILIAN MEIRE DE OLIVEIRA PINTO

MARIA DO CARMO CONTI VAZ DE OLIVEIRA

BRASÍLIA/2011 


\section{Dedicatória}

Dedico este trabalho aos pais de crianças com deficiência auditiva que, contribuiram para essa experiência maravilhosa de conhecê-los e compreende-los. 


\section{AGRADECIMENTOS}

Agradeço ao esposo, filhos amados e colegas do curso, pelo amor, carinho e incentivo que sempre me deram.

Agradeço à Orientadora Valícia Ferreira Gomes, pela dedicação e orientação para a realização deste trabalho. 


\section{RESUMO}

O objetivo do trabalho foi avaliar o impacto sofrido pelos pais ao receberem o diagnóstico da deficiência auditiva do filho e verificar como se processa o enfrentamento dos problemas. Por meio de uma revisão de literatura e pesquisa de campo, procurou-se conhecer as expectativas dos futuros pais ao receberem a notícia da gravidez, compreender os sentimentos e as manifestações psicológicas dos pais de crianças com deficiência auditiva, investigar o papel dos profissionais que atuam junto às famílias de portadores de deficiência auditiva. Observou-se que a notícia de uma gravidez gera nos futuros pais um turbilhão de sentimentos positivos e negativos em relação à criança que vai nascer. A constatação do diagnóstico de deficiência auditiva provoca nos pais um grande impacto e causa mudanças na dinâmica da família, com alterações no relacionamento afetivo e uma redefinição de papéis, atitudes e valores. As principais fases pelas quais os pais passam no processo de aceitação são: negação, resistência, afirmação e aceitação. Tais fases, mostram-se ricas na expressão de sentimentos sobre a deficiência auditiva, em relação aos momentos vividos nesta época. Os resultados deste estudo confirmam a importância das relações de confiança e de parcerias entre os pais dos deficientes e os profissionais que os atendem. Foi possível levantar fatores importantes para o desenvolvimento do trabalho técnico, que os profissionais podem lidar de forma saudável, ao conhecer melhor os sentimentos e as reações dos pais. Deste modo, podem atuar como suporte e encorajamento para esses pais na superação de suas dificuldades ante a deficiência de seu filho.

Palavras-chave: Deficiência auditiva. Família. Diagnóstico. Orientação Familiar. 


\section{SUMÁRIO}

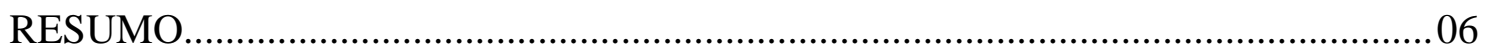

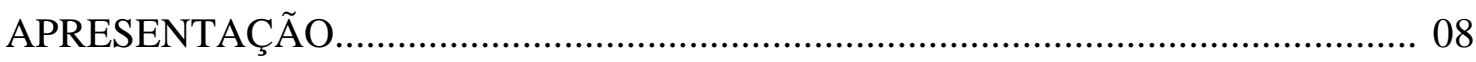

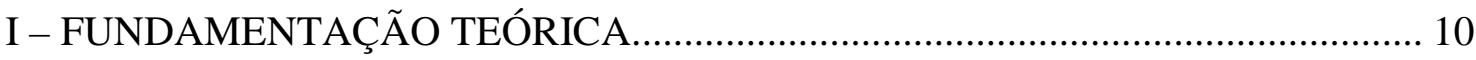

1. EXPECTATIVA DA FAMÍLIA EM RELAÇÃO AOS FILHOS..........................10

1.1 CARACTERIZAÇÃO DA FAMÍLIA....................................................... . 10

1.2EXPECTATIVAS DOS PAIS ....................................................................... 12

1.3A PERDA DO FILHO DESEJADO.............................................................

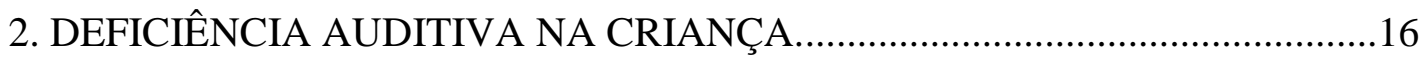

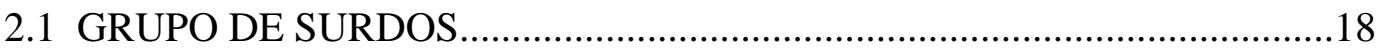

2.2 IMPORTÂNCIA DA AUDIÇÃO PARA O DESENVOLVIMENTO DA CRIANÇA ...............................................................................................19

2.3 CONSEQÜÊNCIAS DA SURDEZ PARA O DESENVOLVIMENTO DA CRIANÇA..............................................................................................20

3. IMPACTO DA DEFICIÊNCIA AUDITIVA E AS REAÇÕES SOBRE OS

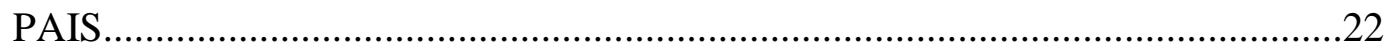

4. O PAPEL DOS PROFISSIONAIS JUNTO ÀS FAMÍLIAS............................25

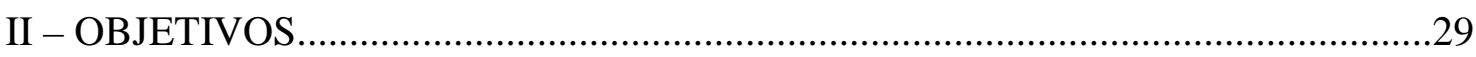

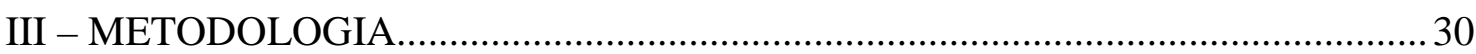

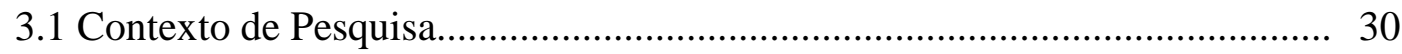

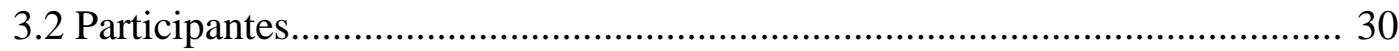

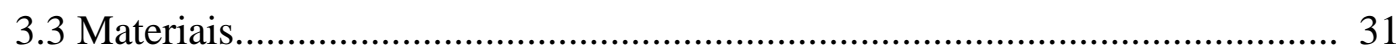

3.4 Instrumentos de Construção de Dados.......................................................... 31

3.5 Procedimentos de Construção de Dados.......................................................... 31

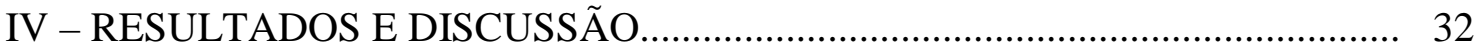

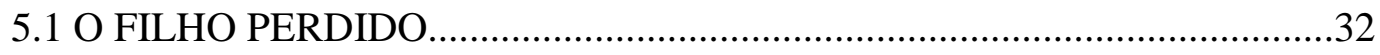

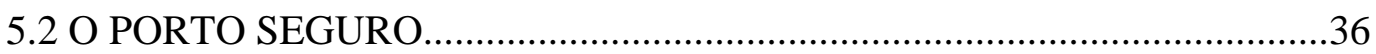

V - CONSIDERAÇÕES FINAIS ............................................................... 42

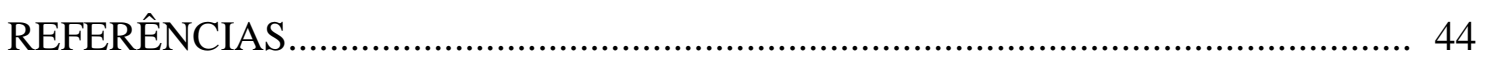

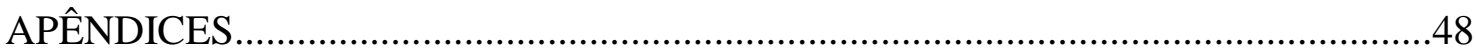

ANEXO 


\section{APRESENTAÇÃO}

Definir Surdez não é uma tarefa simples, pois a surdez, socialmente, não se refere apenas a uma questão de níveis de perda auditiva, mas envolve questões de natureza extremamente complexa (BALIEIRO e FICKER, 1997; CICCONE, 1990). Segundo Ciccone (1990), representar a surdez para nós mesmos é algo bastante abstrato, se somos ouvintes. Se pensássemos em criar um ambiente artificialmente preparado, onde não pudesse entrar um único som, mesmo ali não poderíamos vivenciar o que significa a surdez.

Bastaria que nos recordássemos de uma melodia, do nome de alguém ou de alguma coisa, e estaríamos reauditorizando sons. Estaríamos evocando margens acústicas. Essas experiências são desconhecidas para quem nasceu diferente de nós.

É do conhecimento de todos que uma criança que possui uma diminuição na capacidade auditiva poderá ter sua linguagem prejudicada, isso acontece porque a perda poderá interferir no processo de linguagem assim como no social, emocional, cognitivo e intelectual.

Para Ciccone (1990), a surdez, durante séculos, tem provocado a curiosidade, o interesse e muitas discussões da parte de leigos e profissionais do mundo todo. Apesar do conhecimento científico ter avançado bastante em nossos dias, não raro encontra-se ainda quem julgue como uma doença estranha, ou uma anomalia. Sabe-se hoje que a surdez, é mais do que uma patologia, é uma síndrome. Médicos, assistentes sociais, professores, psicólogos e fonaudiólogos, são alguns dos profissionais que, junto à família, trabalham integralmente no atendimento especializado. O saber científico atual tem podido, de fato, nos afirmar que o surdo é mais do que simplesmente um sujeito que não pode ouvir. Isto quer dizer que ele tem uma diferença, mais do que uma deficiência.

Como a sociedade e as famílias não estão preparadas para enfrentar as diferenças. A presença de um filho deficiente na família exige de cada membro redefinições de papéis e mudanças. Os pais que possuem uma expectativa em relação ao filho, de repente encontramse em situação diferente daquilo que haviam imaginado, planejado e, nesse momento, surge o fato de terem que se tornar pais especiais. Os seres humanos em geral não estão preparados para exercerem o papel de pais de um filho portador de necessidades especiais.

Dar a luz a uma criança deficiente é um acontecimento repentino. Não há aviso prévio, não há tempo para se preparar. Praticamente inexiste um aconselhamento educacional ou psicológico aos confusos pais, nesse momento crucial (...) Grande 
parte do que farão por seus filhos se baseará no instinto ou no método do ensaio e erro. Quanto aos seus sentimentos, medos, ansiedades, confusão e desespero, terão de controlá-los da melhor maneira possível (BUSCAGLIA, 1997).

Quando um dos membros da família nasce surdo, isto gera reações traumáticas, tensão, necessidade e ansiedade, possibilidade de surgimento de conflitos e até mesma desintegração familiar.

É necessário que os pais, na descoberta da surdez no seu filho, saibam como lidar com essas alterações e partilhem suas inquietações com outras pessoas que também passam pelas mesmas fases: o choque, a reação e adaptação.

O que se deseja é desfazer alguns dos mistérios dos sentimentos em relação a surdez para que se torne possível às pessoas reconhecer e compreender o que sentem, de forma que os sentimentos possam ser seus aliados, em vez de seus inimigos.

Sabendo da importância dos profissionais em trabalhar com a família do deficiente auditivo, torna-se necessário as orientações e os aconselhamentos que sejam suficientes para esclarecer os aspectos relevantes da surdez. 


\section{I - FUNDAMENTAÇÃO TEÓRICA}

\section{CAPÍTULO 1 \\ EXPECTATIVA DA FAMÍLIA EM RELAÇÃO AOS FILHOS}

Este capítulo tem primeiro, o objetivo de apresentar alguns conceitos e de trazer uma discussão sobre a expectativa dos pais em relação à chegada do filho no seio familiar. Pretendemos, a partir dos referenciais teóricos, apresentar os sentimentos dos pais em relação ao nascimento dos filhos: suas expectativas, seu sonhos.

Essas primeiras discussões tem por finalidade contextualizar e fornecer uma maior base para a discussão sobre o tema trazido neste trabalho: o impacto e as reações das famílias ao receber a notícia de que seu filho é deficiente auditivo.

Consideramos fundamental descrever, a partir dos estudos bibliográficos as especificidades do deficiente auditivo. Conhecer essa deficiência: sua definição, características, discutir os tipos de surdez e suas classificações, trará para nossos estudos mais embasamento para compreendermos o porquê a notícia dessa deficiência impacta as famílias.

Finalizamos esse capítulo trazendo para nossa reflexão o papel dos profissionais junto às famílias.

\subsection{CARACTERIZAÇÃO DA FAMÍLIA.}

Para Ackerman (1971), família é a unidade básica de desenvolvimento e experiência, realização e fracasso, saúde e enfermidade. Trata-se de um sistema de relações bastante complexo, dentro do qual se processam interações que possibilitam ou não o bom desenvolvimento de cada um dos seus membros.

É o primeiro grupo a que pertence um indivíduo e onde ele tem a oportunidade de aprender através de experiências positivas (afeto, estímulo, apoio, respeito, sentir-se útil) e negativas (frustrações, limites, tristezas, perdas), todas elas, fatores de grande importância para a formação de sua personalidade.

A família é a primeira integradora e o amor, compreensão, confiança, estímulo e comunicação que permeiam a relação, são formas de proteção que utiliza para facilitar o 
processo de integração e participação do indivíduo nos diferentes grupos sociais da comunidade sociedade (MAINARDI \& PESSOTTO, 2008, p. 101-103)

Segundo Buscaglia (1997, p. 84) o papel da família estável é oferecer um campo de treinamento seguro, onde as crianças possam aprender a ser humanas, a amar, a formar sua personalidade mais ampla e mutável, da qual e para qual nascem.

A melhor coisa que a família pode fazer por seus filhos é expressar a sua condição humana, em todas as acepções do termo. Os pais devem saber que são humanos, sentindo-se felizes em fazer o que mais sabem fazer-exercer a sua condição de seres humanos. Este é um bom exemplo para as crianças.

Para as autoras Bevilacqua e Moret (2005, p. 210-215), a família tem um papel fundamental no processo da formação de criança como indivíduo de uma sociedade. Qualquer coisa que aconteça a um membro da família, afeta os subsistemas dos quais ela faz parte, podendo refletir-se no sistema como um todo.

A família é um pequeno sistema social interdependente que contém sistemas ainda menores. $\mathrm{O}$ que somos quando adultos é em função da família e da sociedade cultural das quais viemos. Sabemos que cada família é a única. Com estilo próprio de vida e aprendizado.

Segundo os autores, BRITO e DESSEN (1999), a família é concebida, atualmente, de uma forma mais ampla do que tradicionalmente era vista. Esse novo conceito baseia-se na intimidade entre seus membros, na relação entre as gerações e nas variáveis externas incorporadas à família, o que implica apreender características do relacionamento entre o homem e a mulher e entre as crianças e os genitores, bem como do relacionamento de outras pessoas que também convivem com a família.

\subsection{EXPECTATIVAS DOS PAIS}

A notícia da confirmação da gravidez pode gerar no casal uma euforia profunda. A mulher sente-se poderosa e importante por ter uma vida desenvolvendo-se dentro da sua barriga, e o homem orgulhoso, por fecundar sua mulher e afirmar sua virilidade e potência. Porém, o mais comum é a vivência de sentimentos conflitantes, um misto de alegria e tristeza, medo e coragem, fragilidade e segurança, numa alternância imprevista. Costuma até sugerir a dúvida: "Será que quero ter um filho agora?". E a este pensamento já se anexa outro, que arrasta consigo um sentimento de culpa: "Estou rejeitando meu filho" (ALZUGARAY e ALZUGARAY, 1986). 
É normal, portanto, viver um período carregado de grande emoção, de impactos psíquicos e físicos. Trata-se, em suma, de uma época a ser compreendida e partilhada pelo casal, uma vez que seus conflitos podem ser amenizados através da participação.

Segundo os autores Dessen (1992), Moss (1965), Brito e Dessen, (1999) e Robson (1967), o nascimento de um bebê traz consigo toda uma transformação nos hábitos da família e os estudos mostram que, desde o momento em que a mulher tem ciência de que está grávida, toda uma alteração ambiental se faz presente.

Para Berthoud (1996), as fases iniciais na formação da família caracterizam-se pela união do novo casal e, em especial, pelo nascimento do primeiro filho, quando emocionalmente o casal se constitui como família. Essa é uma fase crítica, considerando que a configuração didática sofre grandes e profundas adaptações no processo de transformação para uma configuração triádica. A crise que se estabelece nesse momento de transição pode ser uma oportunidade de crescimento, como também pode ser vivida como uma situação traumática.

A insegurança é, em geral, tanto maior quanto mais complexo a situação do casal. Verba familiar incerta, problemas profissionais para a mulher e alterações no ritmo de vida do casal envolvido pela gravidez são exemplos de dificuldades práticas que precisam ser consideradas e trabalhadas emocionalmente.

Podem surgir dúvidas em relação ao parceiro: "Será que escolhi direito o pai (mãe) para seu filho? Ele (ela) é bom (boa), mas tem tantos defeitos...”. Geralmente, na vida a dois, o marido-herói e a mulher encantadora já deixaram de existir, cada um passando a se mostrar como é na realidade. A partir do momento em que ambos aceitam os limites e dificuldades do outro e reconhecem as possibilidades de desenvolvimento, o casamento torna-se um solo firme e fértil, onde se conquista a segurança necessária.

$\mathrm{Na}$ verdade, as preparações para se ter um filho já começam na infância. Ao imitar os pais as crianças experimentam os diferentes papéis, e até mesmo a "mamãe-grávida" costuma aparecer, quando a menina adapta uma almofada à barriga e reproduz o jeito de andar e falar da mãe. Na adolescência é comum os filhos dizerem aos pais: "Não quero reprimir meus filhos como vocês fazem comigo", o que demonstra a existência de pensamentos dirigidos ao assunto. Além disso, durante o namoro e o início do casamento, paira a fantasia de como a vida seria caso tivesse um filho. 
Quando a gravidez acontece, planejada ou não, o casal precisa ir-se preparando para uma nova dinâmica da vida familiar, pois um bebê traz mudanças profundas em todos os níveis como alterações na relação íntima homem-mulher, no ritmo de trabalho e lazer, na economia doméstica no espaço da casa, em todo o andamento do dia-a-dia. Dependendo da vontade, e do empenho do casal, todos esses fatores podem passar por um processo gradativo de transformação, de forma a acomodar as novas necessidades e dar abertura para o crescimento e bem-estar de todos.

Quem espera um bebê prepara o espírito para recebê-lo: sonha, faz planos, cuidado do físico e areja a mente. Pelo menos deveria ser esse o plano de vida para toda gestante. Grande número delas, porém deixa-se envolver pelos sentimentos mais contrários, especialmente o temor, durante os nove meses de gravidez. E, quando chega a hora do nascimento, tudo é mais difícil, pois tensão e medo podem transformar um parto, que teria toda a possibilidade, num processo complicado. Por outro lado um parto difícil faz muitas vezes com que a mãe passe a superproteger o filho especialmente se for advertia pelo médico de futuros partos poderão ser perigosos. Outras vezes gera um certo ressentimento por parte do pai por julgar que seu filho não só pôs em perigo a vida da esposa como privou-o de uma família maior (ABRIL CULTURAL, 1970b)

Se a criança foi realmente afetada pelo parto, a tendência à superproteção poderá aumentar ou então ser substituída por desânimo e amargura sentimentos que só dificultarão ainda mais a adaptação da criança. Quando os pais já revelam antes do nascimento uma disposição favorável em relação ao bebê que vai chegar, um parto difícil ou um problema temporária de ajustamento não o modificam essa atitude. Como também um parto normal não torna mais fácil a aceitação do bebê quando ele não é desejado pelos pais.

É por essas razões que o preparo psicológico dos pais é tão importante. Embora o parto represente um pequeno risco físico para a criança, a maioria delas só e afetada temporariamente pelas dificuldades do nascimento, enquanto os pais podem sofrer seus efeitos psicológicos por tempo bem mais longo. Nesse caso, a criança não irá encontrar o clima emocional saudável de que tanto necessita para se desenvolver. Sem dúvida, o ajustamento de cada criança ao novo ambiente depende das condições que as esperam, de como ela é recebida.

Frequentemente os pais idealizam o futuro dos filhos sem considerar os limites de suas potencialidades. Normalmente, quando as aspirações dos pais estão acima da capacidade da 
criança, essa se sente frustrada ao perceber que não corresponde à expectativa. Acaba até não tendo motivação para desenvolver as potencialidades que realmente possui.

Produto da interação entre hereditariedade e ambiente. E, para favorecer o futuro dos filhos, os pais devem proporcionar-lhes um ambiente em que tenham condições para desenvolver ao máximo as potencialidades herdadas. (ABRIL CULTURAL, 1970a.).

\subsection{A PERDA DO FILHO DESEJADO}

Durante o período gestacional, principalmente quando a criança foi desejada e planejada, a família e em especial os pais alimentam uma série de fantasias e projetam no futuro filho os seus próprios conteúdo psíquicos idealizados.

Na grande maioria dos casos, os filhos deverão vivenciar os projetos que os pais não conseguiram concretizar, e estes, por vez, farão o máximo de seu investimento para que as suas frustrações não se repitam na vida dos filhos.

Vivemos, ainda, numa sociedade de classes, com papéis, funções e status préestabelecidos, na qual os indivíduos são valorizados por sua beleza, inteligência e condições de produção, havendo uma grande valorização de trabalho intelectual em detrimento de trabalho braçal.

Como afirma Ackerman (1971), a família é vista como a "unidade básica de desenvolvimento e experiências realizadas e fracasso, saúde e enfermidade”.

É natural, portanto, que, ao tomarem conhecimento de que seu filho é portador de necessidades especiais, os pais se sintam frustrados. Nos casos em que a gestação já havia sido rejeitada, as reações apresentadas são, geralmente, mais acentuadas, pois envolvem sentimentos de culpa:

- As mães expressam sentimento de culpa, referindo-se a algo que haviam feito de errado e que poderia ter causado o problema, como o beber, fumar, não se alimentar adequadamente, ter atividade sexual, exercitar-se, pecar, não ser boa pessoa, não freqüentar a igreja, ter caso extraconjugal e não proceder 
corretamente durante o processo do nascimento do filho (LUTERMAN, 1979).

- As mães achavam que tinha havido algum tipo de erro - aquele não era o seu filho, haviam-no trocado ou o médico havia se enganado quanto ao diagnóstico, um sentimento de perda (PETEAN, 1995).

- As mães sentiram-se inferiores ao receberem a notícia; apresentaram sentimentos negativos acerca de seus corpos bem como em relação ao seu autoconceito.

- As mães sentiram-se confusas e aturdidas. A vida parecia estar desarranjada, as coisas pareciam fora de lugar. Referiam sentimentos nunca experimentados antes e tão confusos como se estivesse num mundo de fantasia: palavras novas sendo utilizadas, novos sentimentos, emoções nunca vivenciadas (Petean,1995).

- Indica-se que haviam desejado morrer mais ou menos uma semana após o nascimento do filho. $\mathrm{O}$ desejo era o de fugir à situação, sendo a morte vista como um dos caminhos para terminar como profundo sentimento de amargura. E não podemos nos esquecer da depressão puerperal nesta fase.

- As mães tiveram sentimento de raiva, ressentimentos, fúria, sem, contudo, saber exatamente com o que ou contra quem estavam zangados. Sentiam raiva diante de toda situação e dirigiram-se contra médicos, enfermeiros, cônjuges, figuras religiosas, seus outros filhos e até contra o próprio bebê. Experimentavam raiva ante seu sonho desfeito (BOORSTEIN, 1996).

- As mães se referiram as necessidades de culpa outras pessoas pelo problema do filho, principalmente médico e enfermeiros. Algumas culparam os maridos, acusando-os de terem mantido relações sexuais com elas, de terem genes defeituosos ou de terem causado estresse psicológico durante a gestação por brigas ou negligência (LUTERMAN (1979).

Segundo Buscaglia (1997), o período de lamentação de si próprias e da criança passa: é hora de encarar "a morte do sonho alimentado a espera de uma criança perfeita". O fato é aguardar os progressos e, dentro dos limites, refazer os sonhos. Outros, inesperados, certamente virão. Devemos ter a consciência de que as limitações da criança devem ser vistas, para que não nos preocupamos com o "onde ela vai chegar", mas sim com o "o que e como 
ela vai fazer", dando-lhe direito a experiências e oportunidades iguais, para que cheguem a realização.

A excessiva ansiedade dos pais sobre um modelo de perfeição que nunca virá, também dará à criança a sensação de que nunca será alguém por completo. Para ele, qualquer bom desempenho ou tentativa, já é motivo para festa. Deve ser assim, também, para os pais.

À medida em que o amadurecimento vem, a ajuda terapêutica e o bom senso convencerão os pais a manterem em primeiro lugar, a sua integridade psíquica enquanto pessoas; em segundo lugar, seu compromisso enquanto pais, para com seus filhos; e em terceiro lugar, sua dedicação e amor para com seus filhos deficientes. Os pais são seres humanos, com expectativas como outro qualquer. Mas para enfrentarmos o problema da chegada da criança deficiente, é preciso que afirmemos que estamos apenas começando. E começando com apenas uma expectativa: a do progresso.

\section{DEFICIÊNCIA AUDITIVA NA CRIANÇA}

Este capítulo apresenta a deficiência auditiva, sua definição e características, discute a diferença entre surdez e deficiência auditiva, descreve os diferentes tipos de surdez e sua classificação em relação à origem, grau, momento da alteração, idade de manifestação e as causas. Ao final do capítulo, são relatadas as conseqüências da surdez para o desenvolvimento da criança.

Segundo Ciccone (1990) a surdez pode ser definida como uma perda ou diminuição considerável do sentido da audição.

O Ministério da Educação (1994) considera uma diferença entre surdez e deficiência auditiva:

- Surdo - é o individuo que não possui audição funcional na vida comum.

- Deficiente auditivo - (ou pessoa parcialmente surda) é o indivíduo que, mesmo com perda auditiva, possui audição funcional, com ou sem prótese.

A surdez pode ser: congênita, hereditária e adquirida:

- Congênita - quando ocorre antes do nascimento ou traumatismo durante o parto. Ex: rubéola materna, toxoplasmose, sífilis, infecção pelo vírus do 
herpes, icterícia neonatal patológica sem tratamento adequado, asfixia (bebês que não apresentam respiração nos primeiros 10 minutos de vida, recémnascidos de baixo peso ao nascer, defeitos congênitos de cabeça ou pescoço, citomegalovírus).

- Hereditária - história familiar de D. A.

- Adquirida - meningite bacteriana, medicação ototóxica, traumatismos, exposições freqüentes a ruídos intensos, etc.

Os tipos de perda auditiva são:

- Perda auditiva por condução (ou perda auditiva condutiva) - quando há lesões no ouvido externo ou médio por resfriados constantes, alergias, fluídos no ouvido médio, inflamações ou infecções no conduto auditivo externo.

- Perda auditiva neurossensorial - ocorre quando há lesão do ouvido interno ou do nervo auditivo. Esta perda pode acarretar, tanto uma redução do nível auditivo, como uma distorção na compreensão da fala (idade avançada, hereditariedade, malformações congênitas, drogas ototóxicas, lesões cerebrais, tumores e exposições a ruídos intensos).

- Perda auditiva mista - ocorre quando há comprometimento de todo o sistema (ouvido externo médio ou interno).

Subdivisões da orelha:

- Ouvido externo: Compreende a aurícula (orelha) e canal auditivo externo.

- Ouvido médio (ou caixa timpânica): compreende os ossículos (martelo, bigorna e estribo).

- Tímpano: localiza-se entre os ouvidos externo e médio.

- Ouvido interno: compreende canais semicirculares, cóclea e nervo auditivo.

- O volume ou intensidade dos sons é medido por unidades chamadas decibel (db). 


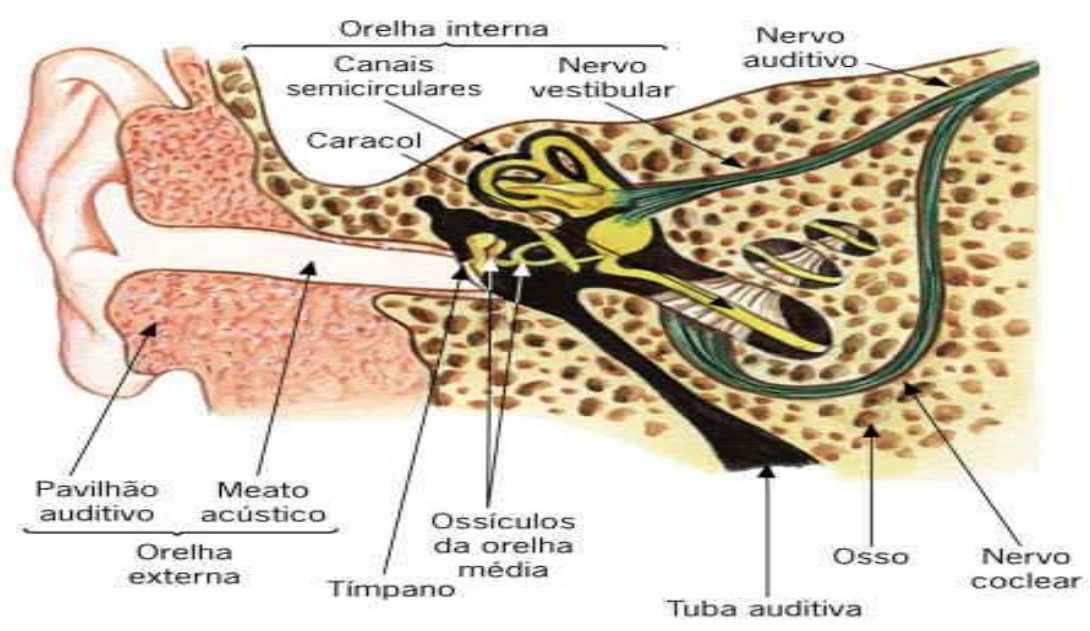

Figura 1. Corte da orelha ( MIROL 2002)

Para Northern e Downs (1984), descreveram os graus de perda auditiva. Para isso utilizaram a seguinte classificação: perda auditiva leve $(26-40 \mathrm{~dB})$, perda auditiva moderada $(31-65 \mathrm{Db})$, perda auditiva severa $(66-95 \mathrm{~dB})$, perda auditiva profunda (acima de $95 \mathrm{Db}) \mathrm{e}$ anacusia ou perda auditiva total.

Lafon (1989) evidencia que a deficiência auditiva pode repercutir na linguagem e na fala, alguns fatores devem ser considerados, tais como: o grau da perda auditiva, a data da sua instalação e a sua localização. No sistema auditivo, uma perda leve pode provocar um retardo da linguagem. Já uma perda média (40 a 70 dB), que inclui as frequiências da fala, certamente ocasiona uma defasagem maior na aquisição de linguagem. As deficiências auditivas profundas (acima de $80 \mathrm{~dB}$ ) podem levar à ausência total de linguagem e expressão verbal. Por isso, o problema deve ser detectado o quanto antes para, assim, ser iniciada a reabilitação.

\subsection{GRUPO DE SURDOS}

A perca da adição é muito grave e pode privar o indivíduo da percepção e identificação da voz humana, impendido-o de adquirir naturalmente a linguagem oral.

Os conhecimentos lingüísticos desses indivíduos (especialmente os sujeitos com surdez profunda) podem apresentar sérias deficiências e dificuldades no que se refere ao domínio de suas estruturas, sobretudo na produção escrita, caso não sejam mediados adequadamente.

Essas dificuldades são perceptívies em relação ao contexto léxico e semântico, falta de consciência de processos de formação de palavras, desconhecimento da contração e 
preposição com o artigo, uso inadequado dos verbos em suas conjunções, tempos e modos, uso inadequado das preposições, omissão de conectivos em geral e de verbos de ligação, troca do verbo ser por estar, uso indevido dos verbos estar e ter, colocação inadequada do advérbio na frase, falta de domínio e uso restrito de outras estruturas de subordinação.

\subsection{IMPORTÂNCIA DA AUDIÇÃO PARA O DESENVOLVIMENTO DA CRIANÇA}

Segundo Ramos (1992), o ser humano inicia a comunicação mesmo antes do nascimento e ela depende da audição. O feto, durante a vida intra-uterina, está familiarizado com alguns sons do meio ambiente, com os batimentos cardíacos maternos e principalmente com a voz de sua mãe. Deste ambiente familiar, ele deverá sair para um ambiente desconhecido na qual a voz da mãe talvez seja um único elemento capaz de lhe dar segurança.

A audição é o principal elo de ligação do ser humano com o ambiente. Para comunicação com os nossos semelhantes precisamos, inicialmente, ouvir e compreender, para então elaborarmos uma resposta e expressa-la através da linguagem.

A partir da $26^{a}$ semana de vida intra-uterina, o feto tem uma capacidade auditiva exatamente igual a de qualquer criança ou adulto normal.

Para Rossi (1996), a audição é a capacidade de ouvir os sons.

A audição é um dos cinco sentidos á nossa disposição para que possamos nos desenvolver bem, captando as informações que o mundo nos fornece.

O órgão da audição é o ouvido, também chamado de órgão vestíbulo-coclear ou estato-acústico a maior parte do ouvido fica o osso temporal que se localiza na caixa craniana. Além da função de ouvir, o ouvido é responsável pelo equilíbrio. Esse órgão é de vital importância para o homem. A audição é necessária para que o individuo possa desenvolver a função da fala e mais tarde a da escrita.

Para os autores Lewis, Raça e, Bevilacqua (1987), é através da audição que a linguagem verbal é adquirida e desenvolvida, já que a fala precisa ser detectada, reconhecida, interpretada e entendida. Portanto, é necessário possuir a integridade do sistema auditivo (tanto no nível periférico como no nível central) e, também, possui a integridade biopscológica do indivíduo. 


\subsection{CONSEQÜÊNCIAS DA SURDEZ PARA O DESENVOLVIMENTO DA CRIANÇA}

Lafon (1989) destacou que a surdez acarreta uma dificuldade de percepção dos sons: há perturbação no conhecimento do meio e na relação oral. A aquisição de linguagem e a gênese da fala em seus aspectos acústicos serão fortemente atingidas.

Tais dificuldades podem ser moduladas pelo grau da surdez, pelas capacidades intelectuais da criança, pelo meio social e pela idade de aquisição da surdez.

Para Lacerda (1976), a deficiência auditiva, quando presente em crianças, aparece como uma ameaça ao desenvolvimento da linguagem.

Segundo os autores Northern e Downs (1984), verificam que a criança surda era caracterizada como sendo prioridade de baixa maturidade social, impulsiva, imatura e egocêntrica.

Os mesmos autores relatam que, quanto mais for adiado a estimulação da função auditiva, menos eficiente será a habilidade de linguagem. Uma criança que, nos seus primeiros anos de vida, é privada de estimulação adequada de linguagem nunca atingirá por completo seu melhor potencial de linguagem.

Os autores Northern e Downs (1984) definiram perda auditiva como sendo qualquer grau de audição que reduza a inteligibilidade de uma mensagem falada, o que dificulta o interpretar e aprender.

Nakamura, Lima e Gonçalves (2000) descrevem que a dificuldade de ouvir os sons do meio ambiente impede a criança de tomar consciência dos sons que ela e outra pessoa produzem ao falar. Sendo assim, ainda bebê, o próprio balbucio não é tão rico como na criança ouvinte.

Tavares (2001), relatou que a criança surda é uma criança que é incapaz de ouvir o som da palavra, mas é um ser de linguagem como outras crianças. A surdez interfere na relação mãe e filho, implicando portanto no processo de aquisição da linguagem. Como o médico é o primeiro a confirmar a surdez, é necessário que esse profissional esclareça as implicações da surdez para a família, a fim de que os pais não formulem expectativa, acreditando que o Aparelho de Amplificação Sonora Individual (AASI) irá substituir a falha orgânica.

Um deficiente auditivo, segundo Almeida (2001), pode ter um desenvolvimento da linguagem e do aprendizado semelhante ao do ouvinte normal, desde que seja adequadamente estimulado. Uma deficiência auditiva, porém, pode levar à alteração das habilidades 
comunicativas e cognitivas, e, ainda, levar à complicações psicológicas, educativas, sociais e econômicas.

As principais conseqüências do diagnóstico da deficiência auditiva congênita, apontadas por Boothroyd (1982):

- Problema perceptual. A criança não pode identificar objetos ou eventos pelos sons que os mesmos produzem, estando mais sujeita a acidentes, pois um importante mecanismo de alerta e defesa encontra-se prejudicado.

- Problema de fala. A criança não aprende a associar os movimentos de seus mecanismos fonoarticulatórios aos sons resultantes. Conseqüentemente, tende a não adquirir o controle da fala, tanto no que se refere à intensidade quando à altura de sua voz.

- Problema de comunicação. A criança não aprende a sua própria língua. Por esta razão, não consegue transmitir seus pensamentos às outras pessoas, exceto por intermédio de gestos e demais ações concretas. Por não entender o que os outros falam, ela fica impossibilitada de manter uma conversação.

- Problema cognitivo. A criança, ao adquirir a linguagem falada, tem acesso ao mundo através dos pensamentos dos outros, das idéias abstratas e das informações sobre épocas ou locais longínquos. A criança deficiente auditiva aprende sobre o mundo a partir de situações concretas: "aqui e agora".

- Problema social. A criança tem dificuldade em desenvolver atitudes adequadas perante os outros, principalmente por não perceber um aspecto da paralinguagem, isto é, os fatores supra-segmentares da fala. Por exemplo: a mudança do tom de voz é um forte indicativo do estado emocional em que o falante se encontra e tal mudança poderia adverti-lo de que passou dos limites. Por não percebê-la, a criança deficiente auditiva tem dificuldade de assimilar as regras sociais, usando, então, comportamentos ritualísticos, manipulando os adultos, a fim de influenciá-los. Como conseqüência, surge o isolamento do mundo e dos outros, isto é, a segregação.

- Problema emocional. A criança, sendo incapaz de satisfazer suas necessidades através do uso da linguagem falada, é incapaz de perceber as reações dos pais e familiares, sentindo-se frustrada, confusa, zangada, medrosa, agressiva e, freqüentemente, desenvolve uma auto-imagem negativa.

- Problema educacional. A criança obtém um benefício mínimo de experiências profissionais, necessitando freqüentemente de educação especial. 
- Problema intelectual. Embora possuidora de inteligência não verbal normal, a criança é deficiente na competência da linguagem e no conhecimento geral. Ela não pode, portanto, através da inteligência, usar seu conhecimento do mundo, para resolver problemas e nem adquirir comunicar, transmitir informações.

- Problema vocacional. A falta das habilidades verbais, do conhecimento geral, do treinamento acadêmico e das habilidades sociais fazem com que o criança deficiente auditiva atinja a idade adulta com possibilidades profissionais severamente limitadas.

- Problema familiar. As reações instintivas dos pais de um bebê que falha em desenvolver a linguagem verbal é deixar de estimulá-lo, não falando com ele, provocando uma redução na interação familiar. Ao descobrirem a real natureza das dificuldades, podem entrar em um estado de confusão, negação do problema e revolta, o que reduz a sua efetividade geral como pais, comprometendo não somente o desenvolvimento da linguagem, mas também a interação socioemocional da criança.

- Problema socioeconômico. A ausência de interação da criança com seus pais será repetida posteriormente pela sociedade como um todo, que tende a estigmatizá-la e segregá-la. A necessidade do uso de um aparelho de amplificação sonora e sua manutenção geram problemas econômicos sérios, devido ao custo elevado dos mesmos, sem levar em conta o trabalho especializado necessário, o qual requer a participação de uma equipe de profissionais.

\section{IMPACTO DA DEFICIÊNCIA AUDITIVA SOBRE OS PAIS}

Este capítulo é apresenta aspectos relacionados ao comportamento e sentimento das famílias de crianças portadoras de deficiência auditiva. Serão discutidas as reações familiares e também o papel dos profissionais no apoio às dificuldades encontradas por essas famílias.

É de nosso conhecimento que existem sinais que podem levar os pais a suspeitarem que seu filho esteja apresentando uma perda auditiva. São sinais como: o balbucio da criança é reduzido ou pára subitamente por volta dos oito meses, sendo substituídos por gritos; a 
criança pode não entender ordens simples e parece ter uma evolução linguística comprometida; a distração é grande, a não reação a sons fortes e ao nome, são alguns dos sinais mais freqüentes para a suspeita de uma deficiência auditiva. Geralmente a suspeita maior é da mãe, que normalmente permanece mais tempo com a criança.

Os pais percebem que algo está errado. E, buscando explicações, vão procurar principalmente o médico pediatra ou o otorrinolaringologista.

A confirmação do diagnóstico, para os autores Nunes (1991) e Holzheim et al. (1997), gera um grande impacto na família, causando a ruptura de expectativas, alterações no relacionamento afetivo, social e de linguagem da família com a criança. A maneira como o diagnóstico é transmitido influencia o processo de aceitação da deficiência auditiva. $\mathrm{O}$ momento em que os pais adquirem consciência do diagnóstico é cercado por sofrimento. Segundo os autores, a reação emocional vivenciada é similar àqueles apresentadas por indivíduos que perderem um ente querido.

Os pais se perguntam: Como devemos amá-lo? Há um sentimento de perda muito grande; perda do filho sadio, idealizado, perda do filho sonhado, a perda do sonho.

É importante que os pais possam viver o choro, a tristeza, o período de luto por esse filho idealizado, sem que lhes seja tirada a esperança, que é o que impulsiona, que é o seu sustento e sem que percam a credibilidade em si mesmos e no próprio filho.

Também é importante que eles consigam não se tornar "pais deficientes", uma vez que terão os seus sentimentos e suas posturas constantemente colocadas à prova, tanto entre eles, como com os profissionais e com o mundo que os cerca.

O tipo de sociedade em que vivemos, na qual predomina o conceito de "normalidade", em que os padrões de beleza, de perfeição física e de inteligência alardeados pelos meios de comunicação são condições essenciais para que o ser humano se realize, faz com que o portador de deficiência seja visto como um cidadão de segunda ou terceira categoria (APAE,1990).

Essa fuga da realidade, aliada ao desconhecimento em relação as deficiência, faz com que o preconceito seja uma atitude predominante nas mais variadas camadas sociais. Nem sempre este preconceito é claro e explícito, na maioria das vezes eles é encoberto por atitudes superprotetoras. O processo de adaptação pode ser visto como um constante viver e reviver de reações e sentimentos, sendo qualitativamente diferente para cada família.

Vários autores, como Luterman (1987), Lafon (1989), Leibovic (1996), Bevilacqua e Formigoni (1997), descreveram as dificuldades que surgem nas relações pais - filhos, na 
presença da deficiência auditiva. Para os autores, o afeto entre pais e filhos se modifica pela presença da surdez na criança. Na fase do diagnóstico, os pais estão perturbados e uma grande tempestade é introduzida na relação pais - filhos, problema este que não está presente na relação de pais e crianças ouvintes. $\mathrm{O}$ momento da confirmação do diagnóstico pode ser definido como um golpe pessoal, no qual os pais têm a necessidade de procurar uma responsabilidade.

Além disso, acrescentam os mesmos autores, os sentimentos mais comuns que ocorrem nos pais de crianças deficientes auditivas são: rejeição, irritação, menosprezo, depressão e aceitação. Esses sentimentos devem ser tratados e elaborados, para que não surjam mecanismos de defesa, como negação ou formação reativa. Tais mecanismos acarretam expectativas irreais, rejeição, superproteção e outros comportamentos similares patológicos.

Os sentimentos de choque e ansiedade são os iniciais, presentes no momento do diagnóstico de deficiência auditiva. Quando os pais são informados que possuem um filho com necessidades especiais, isso representa um desafio de se tornarem "pais especiais", o que provoca um grande medo. A irritação e a depressão aparecem no momento em que os pais descobrem que a criança não pode ser curada, em muitas famílias o sentimento de irritação é reprimido, e essa repressão pode levar à depressão. A culpa e o ressentimento aparecem principalmente em muitas mães de crianças surdas que, em alguma fase, acreditam ser responsáveis pela surdez de seu filho. Nessa fase os pais desejam achar a causa da deficiência auditiva. A vulnerabilidade dos pais os faz superproteger a criança. A confusão e o pânico ocorrem no início do processo. A confusão aparece quando os pais adquirem uma nova informação e isso acaba levando ao pânico. A rejeição é normal a uma situação que é percebida como esmagadora. A rejeição se estende por qualquer aspecto da surdez, como por exemplo, o uso de aparelhos auditivos, no uso de linguagem de sinais ou em alguma outra associação com outros pais de crianças surdas (LUTTERMAN, 1987).

Para Brown (1997), a presença da deficiência do filho fará com que os pais enfrentem um desafio único, do qual não tomariam conhecimento se seu filho fosse a criança perfeita que "sonhavam", sem nenhuma deficiência. Questões perturbadoras permeiam o pensamento dos pais. Dentre elas estão: "Porque isso foi acontecer comigo?”; “Poderei ser um bom pai (mãe) apesar da deficiência de meu filho?”; "Serei capaz de atender a suas necessidades especiais ?”; “Conseguirei suportar as pressões sociais?”; "Poderia custear as despesas financeiras?”; "Serei emocionalmente forte para enfrentar a situação?” 


\section{O PAPEL DOS PROFISSIONAIS JUNTO ÀS FAMÍLIAS}

O momento em que os pais descobrem a deficiência auditiva da criança é cercado de conflitos, sendo, portanto, um momento muito delicado (COLE, 1992). A descoberta da deficiência auditiva costuma deixar os pais muito confusos, derrotados. Qualquer informação que lhes seja fornecida nesse momento dificilmente será compreendida, apenas contribuirá para aumentar seus sentimentos de medo, pânico, inadequação diante do problema. Nessa ocasião uma atitude mais adequada poderia ser a de acolher, ouvir e dar suporte aos pais. Outra atitude seria a de colocá-los em contatos com os outros pais, já que a troca de experiência entre pais de crianças deficientes auditivas pode contribuir de forma mais afetiva, dando-lhe o que nenhum profissional talentoso pode dar (LUTERMAN \& ROSS, 1991).

No programa de pais proposto por Luterman (1979), o foco deve ser centrado nos pais. Esse autor acredita que se os pais forem bem cuidados, as crianças ficarão bem. Outra premissa do programa é tomar conta das necessidades humanas, antes das necessidades "especiais". De nada adianta um adulto surdo bem sucedido, com boa habilidade oral, mas um ser humano infeliz. A criança precisa ser vista em sua totalidade. Antes de ser um deficiente auditivo, ele é uma criança.

Os profissionais devem ter sensibilidade para respeitar esses sentimentos e devem seguir os pais até que estejam mais fortalecidos para compartilhar efetivamente do processo educacional e terapêutico. Se esse limite não for respeitado, o profissional poderá ter pais dependentes e inseguros quanto ao poder em relação a seus filhos, violando os princípios de aconselhamento para formação de pessoas independentes. O profissional precisa ter calma e confiança para passar as informações de maneira gradativa; precisa ainda ter sensibilidade para saber quando e como passá-las, tentando minimizar a confusão inicial gerada normalmente por muita informação recebida em pouco tempo.

Tomar decisões e estar ao lado dos profissionais são fatos que produzem autoconfiança nos pais. Segundo os autores, ter uma criança deficiente auditiva é um chamado para o crescimento dos pais, pois a deficiência do filho fará com que avaliem melhor a vida e que tenham condições de crescer com ajuda do profissional.

Sabendo da importância dos profissionais em trabalhar com a família do deficiente auditivo, torna-se necessário esclarecer dois procedimentos distintos: orientação e aconselhamento. 
Para Luterman (1987), orientar consiste em oferecer conselhos, persuadir, confrontar, gerar insight, e promover uma relação "quente" e de aceitação com o cliente. Aconselhamento foi definido pelo mesmo autor como sendo uma experiência educativa que acontece entre as pessoas que acabam centralizando o problema permitindo, então a expressão de sentimento, e encorajando o crescimento de ambas as partes. Aconselhamento é mais do que troca de informação é mais que oferecer conselhos. O autor conclui que, os profissionais, para ser eficiente necessitam se encaminhar para os termos afetivos.

Harrison (1994) refletindo sobre a questão do aconselhamento, relatou que o termo aconselhamento mostra-se mais adequado quando encarado como um relacionamento baseado no respeito mútuo pelas diferenças que possam surgir entre pessoas, pelos sentimentos que serão colocados e pelas decisões que se venha a tomar. Para a autora é essa informação que os pais e os profissionais precisam reconhecer ao escolherem os atendimentos que buscaram para seus filhos e pacientes.

Grande parte da literatura atual sobre aconselhamento descreve a importância dos pais participarem de um grupo, no qual eles, possam expressar, com segurança a raiva e o desapontamento e ouvir os que os outros pais sentem.

Normalmente os pais demonstram uma certa sensação de alivio ao descobrirem que não são os únicos em sua reação à deficiência auditiva do filho.

Postura Desejável dos Profissionais:

- Disponibilidade para ouvir os pais; atenção voltada para a família evitando julgar e criticar, procurando criar uma comunicação.

- Oferecer orientações e informações; auxiliar na identificação e compreensão das necessidades desse filho. Envolvê-los afetivamente, relação como seres humanos.

- Oferecer modelo, envolver os pais em programas, palestras, sem exigir mais do que tenham condições de dar.

- Auxiliá-los em suas escolhas frente às diferentes alternativas.

- Procurar desenvolver um trabalho de parceria - descobrir com eles, que o fato de terem um filho com uma deficiência não lhes tira o direito de sorrir, de reclamar, de chorar, de serem humanos.

- Oferecer modelos para auxiliá-los a se valorizarem como pessoas.

- Facilitar relação mais próxima dos pais com os seus filhos - falar de seus sentimentos. 
Segundo Bevilacqua e Formigoni (1997), existem três fatores que determinam o êxito do trabalho de habilitação da criança deficiente auditiva. $\mathrm{O}$ primeiro fator relaciona-se ao envolvimento de toda a família no tratamento dessa criança. Os irmãos merecem atenção especial, uma vez que é comum terem sentimentos de culpa por sua normalidade, raiva pelo problema do irmão e ciúme em relação a atenção especial dada ao irmão deficiente. O segundo fator diz a respeito à melhora da auto-estima dos familiares, principalmente, das mães. Aquelas que se envolvem mais com os filhos são mais ativas, assumem maior a responsabilidade, acabam por aumentar e melhorar sua auto-estima. O terceiro e último fator relaciona-se ao sentimento de que a educação da criança está sendo partilhada por todos os membros da família. A família é a chave do sucesso, uma vez que o trabalho terapêutico é restrito a um encontro, um momento. Os pais passam para a criança a maior parte das informações sobre o mundo, em um percurso que vai desde o nascimento, adolescência, vida profissional e adulta.

Para Bernard e Erickson (1986), os pais são os primeiros mestres, sua atuação inicial de aceitação ao filho com necessidades especiais torna-se penosa: imobilizados pelo "novo" e desconhecido, necessitam do auxílio de profissionais competentes, com mentalidade aberta, para lidar com reações emocionais de negação, frustração e retrocesso.

É fundamental que o terapeuta ofereça apoio à família, a fim de planejar seu tempo, seus recursos financeiros e suas ações frente a criança.

A sua principal função deve ser a "de aumentar seus sentimentos de adequação como indivíduo e como pais, auxiliando-os nas formas de responder à criança em desenvolvimento, mesmo que seja tão diferente".

Respostas vagas e sem sentimentos, automáticas vão resultar em uma falsa segurança dos pais.

O momento em que os pais recebem a notícia da problemática que envolve seu filho é o momento do "corte" na relação de ligação entre mãe e filho. Restabelecer esse elo é papel, principalmente, do terapeuta.

Os pais, (pai e mãe, juntos!) devem procurar comparecer as entrevistas com o terapeuta, porque seu filho "diferente" não será o único a necessitar de intervenções clínicas: suas vidas também tornam-se diferente com a chegado do filho. Outro motivo é que ambos devem responsabilizar-se pelos cuidados com a criança.

Não é do domínio de técnicas de diagnóstico do médico que impressionaram aos pais, é a maneira como conduzirá cada encontro. 
A atuação desse profissional deve dar-se tanto no lar quando na escola: o terapeuta e a criança devem buscar juntos, a fonte para a manifestação de certos comportamentos da criança em casa e na sala de aula, tendo esta a necessidade de conscientizar-se das adversidades que seu comportamento inapropriada ocasionou.

O objetivo maior do terapeuta deve ser o de trazer os pais para junto da criança, provocando um envolvimento entre eles.

A aceitação da deficiência deve ser mútua (entre o casal); e o filho não deve nunca ser culpado pela tensão no lar, ou por um possível abandono de um dos cônjuges.

A complexidade de exercer-se o papel de pais do deficiente auditivo pode e deve ser diminuída pela atuação do terapeuta, no encorajamento de aceitarem o desafio que tem pela frente. Não precisam, de início, “aceitar coisa alguma, exceto o desafio que acompanha o ato de assumir a responsabilidade de crescer, realizar seus potenciais, aprender e tornar-se um ser humano melhor, ao lado de sua criança especial. Tudo a mais vem a seguir".(BUSCAGLIA 1987, p. 99). Seu crescimento pessoal tem que vir primeiro, porque só poderão ajudar aos filhos se estiverem aptos a transmitir-lhes forças de espírito e qualidades! 


\section{II - OBJETIVOS}

Objetivo Geral:

Este trabalho tem como objetivo geral compreender o sentimento de pais ouvintes em relação ao diagnóstico de seus filhos surdos.

Objetivo Específico:

Como objetivos específicos esse trabalho pretende:

- Conhecer as expectativas dos pais sobre o futuro de seus filhos;

- Investigar os sentimentos dos pais frente ao diagnóstico da deficiência auditiva no seu filho;

- Discutir o papel dos profissionais da educação especial na relação com a família de crianças surdas. 


\section{III - METODOLOGIA}

\subsection{FUNDAMENTAÇÃO TEÓRICA}

A pesquisa foi desenvolvida tendo como base o método qualitativo, revisão e fundamentação bibliográfica, sendo considerado para a apreciação dos resultados entrevistas gravadas e relato sobre as percepções dos participantes sobre três perguntas (ANEXO 1)

\subsection{CONTEXTO DE PESQUISA}

O local escolhido para a pesquisa é uma escola estadual centenária, E.E. Cel. Fernando Prestes, tombada e tradicional do município de Itapetinga, situada no centro da cidade, onde a sala de recursos está em funcionamento desde o ano de 2000. Antes desta data a mesma existia com classe especial desde a década de 70.

Esta Modalidade de atendimento atende os alunos com surdez de grau leve a profundo, que fazem ou não uso da Língua de Sinais (LIBRAS) como forma de comunicação, em regime de contra turno escolar.

Atualmente conta com 15 alunos frequentando no período da manhã estando distribuídos entre a $3^{\mathrm{a}}$ série do ensino fundamental a $3^{\circ}$ ano do ensino médio.

Os alunos frequentam, semanalmente de duas a três horas por um período de 2 horas, por atendimento cada um, em sistema de rodízio, com horário pré-agendado e em grupos de até 4 alunos ou individualmente.

\subsection{PARTICIPANTES}

Foram entrevistadas 15 mães, com idade entre 35 a 49 anos, sendo que quatro delas têm ensino fundamental incompleto, uma, ensino fundamental completo e o restante sem nenhum grau de escolaridade, um fato semelhante é que todas trabalham e contribuem para uma renda familiar em torno de $\mathrm{R} \$ 1.000,00$ a $2.000,00$. 


\subsection{MATERIAIS}

Os recursos utilizados na pesquisa de campo foram: gravador, materiais de consumo como: papel e cante esferográfica.

\subsection{INSTRUMENTOS DE CONSTRUÇÃO DE DADOS}

Os instrumentos de Construção de Dados para o levantamento de informações foram entrevistas e observações dos relatos com as mães ouvintes da Escola Estadual do município de Itapetinga, bem como pesquisa bibliográfica.

\subsection{PROCEDIMENTOS DE CONSTRUÇÃO DE DADOS}

Os critérios que me levaram a escolher a unidade escolar E.E. Cel. Fernando Prestes, foi à professora que leciona nesta unidade escolar com alunos com surdez, pois a conheço e me ajudou na organização dos dias e horas dos participantes com as mães dos alunos, onde foi esclarecido o porquê da entrevista com as mesmas. A entrevista foi realizada em 4 dias, durante 2 horas por dia.

Assim, os dados foram obtidos por meio de entrevista individual com as mães, após explicações do estudo e da assinatura do documento Termo de Consentimento Livre e Esclarecido.

As entrevistas foram gravadas e, durante o relato das seis mães, foram anotadas algumas observações como: a importância de algumas pessoas da família neste processo, a importância dos profissionais da educação e da saúde neste processo e as relações sociais dos pais.

A entrevista foi estruturada de forma que fosse possível analisar os seguintes tópicos: Que idade tinha seu filho quando foi descoberta à surdez? Como foi descoberta e quem suspeitou que o seu filho não ouviria? Qual foi a reação inicial da descoberta da surdez nos pais? 


\section{IV - RESULTADOS E DISCUSSÃO}

Para analise de resultados e discussões das 15 entrevistas com as mães, conforme abordado na metodologia, somente seis foram apresentadas, pois foram observadas semelhanças nas respostas, portanto para propiciar maior veracidade nas informações, são apresentados seis relatos, respeitando as perguntas abordadas na entrevista (ANEXO 1) e contemplando duas categorias: A primeira denominada por " $\mathrm{O}$ filho perdido", onde foram observados nos relatos ao descobrir e diagnosticar a surdez e a segunda categoria denominada por "O Porto Seguro", onde são descritas as ações pós descoberta da surdez.

\subsection{O FILHO PERDIDO}

Essa categorial contempla os relatos das entrevistas realizadas com as mães de filhos surdos, sendo apresentados as respostas referentes ao Roteiro de Entrevista (ANEXO 1): Que idade tinha seu filho quando foi descoberta à surdez? Como foi descoberta e quem suspeitou que o seu filho não ouvia? Qual foi a reação inicial da descoberta da surdez nos pais?

\section{Relato 1:}

Mãe M.S., filho L.S., sexo masculino, idade 15 anos.

A mãe de L.S. relatou que descobriu a surdez de seu filho aos quatro anos de idade, na verdade quem descobriu foi a esposa do Administrador da fazenda, localizada no interior do estado de São Paulo, onde moravam.

\footnotetext{
"A esposa do Administrador chama por ele, mas ele não reagia. Ela suspeitava que ele fosse surdo, mas eu e meu marido não acreditávamos nela. Na verdade meu marido ficou bravo, só que depois a gente foi prestando mais atenção nele. Até que um dia com ele de costas para nós eu e meu marido começamos a fazer barulho
} 
com tampa de panela, bater a porta com toda a força e gritamos, nem sei mais o que.

E ele não reagiu, ficamos arrasados! Já imaginando que nosso filho teria uma vida difícil, que seria tratado com preconceito por todos. Meu marido demorou mais para aceitar do que eu.

Os tios e avós procuraram dar apoio, mas ninguém sabia como falar com ele. Nas festinhas ele ficava meio isolado, só junto com nós (pais e irmãos). Na verdade, nem a gente sabia direito como conversar com ele. Ele sempre apontava o que queria e a gente dava."

\section{Relato 2:}

Mãe M.A.C, Filho E.A.C, sexo masculino, idade 14 anos.

"Eu descobri a surdez do meu filho quando ele tinha aproximadamente dois anos de idade.

Com quatro dias de vida ele teve hepatite e ficou nove dias na UTI, com três meses eu percebi que ele tinha o corpo muito mole e levei no neurologista da equipe de profissionais da APAE de Álvares Machado em São Paulo, meu filho frequentou a estimulação por quatro anos, possui sequelas no desenvolvimento físico e cognitivo. $O$ médico falou que ele não iria andar. Meu marido e eu ficamos muito nervosos. Nesse período desconfiamos que ele não ouvia, pois os barulhos de caminhão, batida de porta e outros barulhos no ambiente ele não acordava e não se assustava.

Com a confirmação da surdez eu e meu marido ficamos muito tristes, chorei bastante por vários dias, ele já tinha outros problemas.”

\section{Relato 3}

Mãe S.M.S, Filha R.M.S, sexo feminino, idade 10 anos.

"Eu descobri a surdez na minha filha quando ela tinha um ano e meio de idade. Com cinco meses ela teve infecção no ouvido e durante o período até completar um ano de idade ela fez cinco vezes lavagem no ouvido, depois disso teve uma febre muito alta que o médico não 
soube dizer a causa. Ela passou por três médicos, onde o terceiro que descobriu o rompimento do tímpano, ou seja, que ela era surda. Eu já desconfiava que algo estava errado, notei que ela não falava as palavras que normalmente toda criança já começa a falar como: mamãe e papai.

Fique confusa como se o chão tivesse aberto e não sabia onde pisar, sentimento de insegurança, medo invadiu minha pessoa.

Pensei, ela não nasceu surda, ela ficou surda, não consegui chorar mais senti uma dor que não sei como explicar. Foi difícil sufocar essa dor que senti dentro meu peito por vários anos".

\section{Relato 4}

Mãe J.S., Filho R.F.S, sexo masculino, idade 12 anos.

"Descobri a surdez de meu filho com 8 meses após seu nascimento, levava-o todos os meses no pediatra, por coincidência no consultório caiu da prateleira um brinquedo de plástico duro no chão que fez um barulho que assustou eu e o medico, mas meu filho não teve nenhuma reação ao barulho. $O$ medico muito delicado me orientou a levá-lo no otorrinolaringologista por ele não se assustar com o barulho que aconteceu na sala.

Deste dia em diante fiquei muito ansiosa e preocupada até o dia da consulta, contei os dias para chegar depressa, tive o diagnóstico positivo, 'o meu filho é surdo!'

No primeiro momento fiquei com muita raiva e até revoltada com Deus. Perguntava: por que Deus, eu fiz alguma coisa de tão errado para merecer esse filho que esperei com tanto amor? E agora ele é surdo, como vou cuidar dele? Que escola ele vai ter de estudar? O que será do futuro dele?

Fiquei desesperada, voltei para casa com sentimentos de raiva, revoltada, completamente perdida, chorei muito o resto do dia."

\section{Relato 5:}


Mãe A.R.F., Filho B.R.F, sexo masculino, idade 08 anos.

"A surdez foi descoberta quando meu filho tinha um ano de idade. Foi minha mãe que percebeu que ele gostava de assistir a TV com o som muito alto e quando ela abaixava o som ele chorava. Minha mãe comentou que ela achava que ele não escutava bem, fiquei muito brava com ela, falei: Mãe ele só tem um ano de idade! E esta descobrindo as coisas!

Então minha mãe sugeriu que eu o levasse para o otorrinolaringologista e ela mesmo me ajudou a pagar a consulta e o exame.

$O$ resultado do exame foi positivo, ele tem surdez. Eu ignorei o resultado do diagnóstico, pois não queria aceitar, minha mãe aceitou bem o resultado, acho porque foi ela mesma que viu que algo estava errado com ele."

\section{Relato 6}

Mãe F.S., Filho J.S., sexo feminino, idade 15 anos.

"A descoberta de surdez em minha filha foi quando ela tinha um ano e oito meses, eu percebi que ela não escutava, pois ela não percebia o barulho de carro, gritos, palmas. Daí eu fui em um hospital de Ribeirão, onde foi feito todos os exames que constatou surdez.

O medico foi bem grosso e falou 'na lata' que minha filha era surda e teria de estudar em escola especial. Foi um choque para mim, fiquei paralisada quando recebi a notícia, muitas coisas passaram em minha cabeça naquela hora, "E agora o que eu faço! Como é a vida de um surdo? Será que é normal?”

Eu olhei para ela com um olhar de pena e dó, imaginando como iria ser, como ela ia crescer, como eu vou conversar com ela e comecei a chorar muito.

Fui para a casa arrasada contei para o meu marido que ficou muito nervoso e desgostoso com a situação. 
Passou a não ligar para a filha, notei que ele mudou, se tornou frio com ela e comigo e depois de dois meses ele nos abandonou. Voltei para a cidade onde eu morava com meus pais antes de casar."

Ao analisar esses relatos fica evidenciado que para todas as mães o recebimento da notícia da surdez foi um choque e que estas famílias não estavam preparadas para receber um filho com surdez. Esses relatos confirmam o que os autores Luterman (1979) e Petean (1995) afirmam, nos quais os pais ao receber a notícia reconhecem a calamidade da situação e sentimentos começam a emergir: medo, remorso, raiva, negação.

Algumas mães, confirmando o que diz Miller (1995) sobre as definições de aceitação, demostraram buscar marcas de normalidade na criança. Outras mães demonstravam com o tempo uma boa adaptação à situação e outras ainda têm sentimento de insegurança com o futuro de seus filhos.

Para Miller (1995, p. 99), a primeira aceitação é receber de bom grado a noticia. A segunda é "admitir a existência da situação, digeri-la e conviver com ela, da melhor maneira possível". Nesse sentido a mãe ao buscar marcas da normalidade na sua criança, aceita seu filho, porém atura a deficiência, apesar da insegurança e do medo do futuro.

\subsection{O PORTO SEGURO}

Quando nós deparamos com a morte de um sonho buscamos alguém que segure nossa mão, enxugue nossas lágrimas e nós de a esperança de um novo sonho.

Nessa categoria denominada como "O porto seguro" são apresentados os relatos respondidos referente a "Qual a real situação de integração e inclusão pós diagnóstico?”.

Os relatos apresentados mostram-nos que a inclusão começa na família, através daqueles que de certa forma nos levam a tomar uma iniciativa, buscando profissionais que ajudarão a compreender a deficiência e a ajudar o filho deficiente a superar suas limitações e a se desenvolver de acordo com suas especificidades (JESUS. 2009, p.17).

A aceitação da família pode garantir a criança deficiente atendimento de profissionais da área. Nesse sentido e, ouvindo as vozes dos entrevistados, apresentamos um paralelo com alguns autores, apontando a importâncias dos profissionais para a inclusão desses sujeitos, na família e na escola. 


\section{Relato 1:}

Mãe M.S., Filho L.S., sexo masculino, idade 15 anos.

“Meu filho foi levado pelo administrador e pelo dono da fazenda para São Paulo, para fazer exames. A 'fono' explicou que ele ia precisar fazer sessões de fono para aprender a falar.

Foi feito um tempo, mas foi difícil continuar porque a gente morava longe, ele colocou aparelho e quando já estava com quase dez anos foi pra a classe especial para surdos. Lá ele aprendeu muitas coisas como escrever, mas não igual a gente um pouco diferente, fazer contas, procurar cidades no mapa, entre outros. Depois a gente mudou de fazenda, pra trabalhar e ele acabou saindo de lá.

Depois foi crescendo e começou a aprender o serviço da fazenda pra ajudar o pai.

Na escola, na sala que todos também são surdos, aprendeu a língua de sinais e sua comunicação melhorou e sua aprendizagem também. Eu estou contente por ele, mas é muito difícil lidar com a surdez."

\section{Relato 2:}

Mãe M.A. C, Filho E.A.C, sexo masculino, idade 14 anos.

"Não me revoltei com 'Deus', sou uma pessoa de muita fé se 'Deus' me deu um filho assim, vou cuidar com muito amor, carinho e dedicação.

Atualmente ele estuda aqui na escola na sala de recurso e está aprendendo, já estou conseguindo entender alguma coisa da língua de sinais, ele é um filho muito amoroso e companheiro, adora jogar bola na escola da família perto de casa todos os sábados e domingo.

Estuda nesta escola onde está aprendendo e fazendo amigos. Estou muito feliz. 'Graças a Deus'.” 


\section{Relato 4}

Mãe J.S., Filho R.F.S, sexo masculino, idade 12 anos.

'Quando o meu marido voltou do trabalho contei a ele e sua reação foi melhor do que a minha, ele ficou triste, mas demonstrou aceitar o nosso filho e disse para mim: Nós dois juntos iremos ajudá-lo no que for possível, tenha certeza. Abracei meu marido e chorei, uma sensação de alivio invadia a minha alma.

Meus pais me dão muito apoio, foram eles que ajudaram a encontrar está escola para ele estudar e estou satisfeita, está aprendendo e tem vários colegas, onde se dá muito bem.

Estou aprendendo os sinais e está mais fácil eu entender e se comunicar com ele. Mesmo assim, de vez em quando me pergunto por que será que ele veio assim? Mais, pela dificuldade que a gente encontra em se comunicar com ele e pela sociedade onde vê a surdez como uma deficiência e não como uma diferença."

\section{Relato 5}

Mãe A.R.F., Filho B.R.F, sexo masculino, idade 08 anos.

\footnotetext{
"Minha família e meu marido me deram o maior apoio e procuramos a Associação para deficientes auditivos, onde eu levei meu filho e daí por diante passou a ter aulas de fono e começou a usar o aparelho auditivo.

Hoje ele frequenta aqui a escola e está aprendendo ler, escrever, pintar, tem colegas. Ele aprende com maior dificuldade e é mais lento no seu aprendizado, mas ele aprende. Frequenta a AAADAI uma vez na semana.”
}

\section{Relato 6}

Mãe F.S., Filho J.S., sexo feminino, idade 15 anos.

\footnotetext{
"Depois de meu marido ter nos deixado, voltei para a cidade onde eu morava com meus pais antes de casar.
} 
Lá eu encontrei o meu segundo marido, ele respeita a minha filha como se fosse dele, me levou na igreja Batista, onde eu aprendi a língua de sinais e hoje minha filha e eu nos comunicamos muito bem e ela faz parte da comunidade de jovens da igreja. Tem muitos amigos ouvintes e surdos.

Frequenta está escola que me parece acolhedora, sua socialização com os colegas e funcionários da escola é muito boa. Conversa muito com a professora e fala que seu rendimento escolar é satisfatório. Seu aprendizado é bem visual, é uma jovem alegre e posso afirmar que ela vive uma vida normal como qualquer jovem.

Estou muito feliz por ela, mas posso afirmar que ainda tem dias que sentimentos de tristeza e preocupação e insegurança ainda acontecem."

Como podemos analisar é preciso seguir em frente, deixar o que Buscaglia (1997) chama de período de lamentação, procurar ajuda e viver os processos para refazer os sonhos.

A pesquisa de campo mostra-nos a realidade do impacto causado nas famílias: dor, medo, separações, vergonha, sentimento de culpa. Segundo Nunes (1991) a comprovação de uma deficiência de um filho provoca situações de crise na família. Outros autores procuraram também investigar e descrever os acontecimentos que surgiram ao se deparar com essa realidade, apontando que os pais "sempre" sentem a necessidade de saber a causa da deficiência auditiva (LUTERMAN, 1987. LEIBOVIVI, 1996. BEVILACQUA E FORMIGONI, 1997).

Esses sentimentos são, diante destas referências comuns a qualquer família, o que pudemos observar é que, no processo de aceitação, todos precisam de um "porto seguro": de alguém que os escute, de alguém que compreenda seus sentimentos e responda a seus questionamentos, suas dúvidas (LUTERMAN, KURTZER-WHITE E SEEWALD, 1999).

Mas afinal qual é o papel daqueles que estão envolvidos nesse processo, quem são esses sujeitos que podem e devem ser o porto seguro dessas famílias?

Os sujeitos são, segundo esta pesquisa de campo, aqueles que estão dispostos a ajudar, que se colocam no lugar do outro e, se comprometem com a dor do outro. Aqueles que são capazes de amar e superar seus próprios preconceitos, mostrando-nos que só os superamos convivendo e aprendendo no dia-a-dia com todos os envolvidos neste contexto e com o próprio sujeito deficiente. 
Esta pesquisa de campo mostra-nos também, que esta aceitação é apenas um primeiro passo, no processo viram outros aspectos que certamente geraram outros sentimentos, outras descobertas: a comunicação desses sujeitos, as relações sociais, o uso do aparelho auditivo, a educação escolar.

Nesse sentido evidenciamos o papel dos profissionais de saúde, entre eles o do terapeuta, no entanto Buscaglia (1997) adverte que podemos encontrar dados sobre satisfação ou insatisfação de pais, com relação ao atendimento clínico recebido: vão desde reclamações de sua "distância profissional", falta de simpatia tendência a rotular os pais como "resistentes", até relatos de satisfação para com a orientação recebida são dados suficientes para escrever um livro só de relatos de pais, e até de professores, sobre a qualidade do atendimento clínico para os deficientes, em geral, e aos surdos em particular.

É essencial que os pais não busquem perder muito de seu tempo variando de profissional terapeuta, exceto se os dados fornecidos pelo primeiro forem vagos ou insuficientes. O medo e ansiedade levam os pais a duvidar dos diagnósticos iniciais, buscando outros, complementando-os. Conclui-se então que, primeiramente o terapeuta seja solidário com a família (BUSCAGLIA, 1997), seja também um porto seguro.

Colocamos também a escola como um porto seguro, que por determinação legal, não pode se esquivar desse desafio. O professor do deficiente auditivo deve ser, também, um profissional capacitado para desenvolver com ele um programa inclusivo, mas, é essencialmente que esse educador não desconheça nenhum dos pontos do histórico desse aluno! Necessita, contudo, conhecer o que esperar dessa criança, o que exigir e o que é preciso para interessá-la.

Segundo Cole (1992), os profissionais precisam ter em mente que a experiência de cada indivíduo é única e que a descoberta de que a criança é portadora de uma deficiência auditiva modifica, de alguma forma, o comportamento individual e familiar.

Neste contexto, espera-se dos Profissionais:

- Disponibilidade para ouvir os pais; atenção voltada para a família evitando julgar e criticar, procurando criar uma comunicação.

- Oferecer orientações e informações; auxiliar na identificação e compreensão das necessidades desse filho. Envolvê-los afetivamente, relação como seres humanos.

- Oferecer modelo, envolver os pais em programas, palestras, sem exigir mais do que tenham condições de dar. 
- Auxiliá-los em suas escolhas frente às diferentes alternativas.

- Procurar desenvolver um trabalho de parceria - descobrir com eles, que o fato de terem um filho com uma deficiência não lhes tira o direito de sorrir, de reclamar, de chorar, de serem humanos.

- Oferecer modelos para auxiliá-los a se valorizarem como pessoas.

- Facilitar relação mais próxima dos pais com os seus filhos - falar de seus sentimentos. 


\section{V - CONSIDERAÇÕES FINAIS}

Considerando as argumentações e embasamentos fundamentados em referências bibliográficas, foi possível observar que a notícia de uma gravidez causa surpresa à mulher e seu companheiro, mesmo se estivessem desejando ter um filho. Esse impacto costuma atingir todos os casais, e suas reações vivenciadas no período inicial da gestação.

Essa confirmação literária (LUTERMAN, 1987. LEIBOVIVI, 1996. BEVILACQUA E FORMIGONI, 1997), revela-nos pensamentos, emoções, sensações e sentimentos conflitantes, uma mistura de alegria e tristeza, medo e coragem, fragilidade e segurança. $\mathrm{O}$ surgimento da dúvida é normal, porque há a vivência de um período carregado de grandes emoções, de impactos psíquicos e físicos.

A família é um sistema em constante transformação e o fato de um filho apresentar deficiência auditiva pode provocar uma crise no meio familiar. Neste estudo, o foco de interesse foi investigar as expectativas e sentimentos e conhecer as reações dos pais de crianças deficientes auditivos por meio de pesquisa literária.

Na visão de alguns estudiosos como Buscaglia (1997), Luterman (1987), Nunes (1991), que citam as reações dos pais diante do diagnóstico da deficiência auditiva, são demonstradas claramente as reações de sofrimento, choque, negação, frustrações pelos pais. Viver a dor é muito difícil para esses pais e isto faz com que se expressem por outros meios.

Nesse momento, o contato com outros pais é necessário, pois eles precisam trabalhar esses sentimentos sufocados.

Após a comunicação do diagnóstico, há a necessidade de compartilhar os sentimentos, conhecimentos e o contato com outras pessoas na mesma situação; pode ser uma possibilidade de aprendizagem, devido ao fato de que esses pais estão passando ou já passaram pelas mesmas fases. Luterman (1987) relata que nesse momento o foco mais importante são os pais. Se os pais estiverem bem, a criança também estará bem. Sendo assim, propiciar o encontro de pais em grupos de discussão e de apoio pode ser uma das formas de ajudá-los.

Portanto, para oferecer uma assistência mais adequada às famílias, no período logo após a comunicação do diagnóstico de deficiência auditiva, os profissionais de educação e saúde necessitam preparar-se. Faz-se necessário um aprofundamento dos seus conhecimentos na área de aconselhamento e acolhimento das famílias. Desta forma, torna-se possível auxiliar 
verdadeiramente os pais na relação com seus filhos deficientes, desde os primeiros momentos vividos nessa nova realidade. 


\section{REFERÊNCIAS}

ABRIL CULTURAL. Nossas crianças. Vol 6, São Paulo, 1970a.

ABRIL CULTURAL. Nossas crianças. Vol 9, São Paulo, 1970 b.

ACKERMAN, N. W. Diagnóstico y tratamiento de las relaciones familiares. Bueno Aires, E.d Hormé, 1971

ALMEIDA, R.R. Diagnóstico precoce da Deficiência Auditiva. In: FONSECA, V.R.J.R.M. Surdez e Deficiência Auditiva: a trajetória da infância á idade adulta. Casa de psicólogo, São Paulo, 2001.

ALZUGARAY, D.; ALZUGARAY, C. Uma criança vai nascer. São Paulo:Três, 1986.

APAE / SÃO PAUlO. VOCÊ NÃO ESTÁ SOZINHO: Temos um Filho Especial. Publicação do Projeto Momento da Noticia. São Paulo: Associação de Pais e Amigos dos Excepcionais, 1990.

BALIEIRO, C.R; FICKER, L.B; Reabilitação Aural: a clínica fonoaudiológica e o deficiente auditivo. In: LOPES FILHO, O. Tratado de Fonoaudiologia. São Paulo: Ed. Roca, 1997.

BERNARD.K. \& ERICSON.M.L. Como Educar Crianças com Problemas de Desenvolvimento $2^{\circ}$ edição Rio de Janeiro, Globo, 1986.

BERTHOUD, C.M.E. O Nascimento psicológico da família [resumo]. Em Sociedade Brasileira de Psicologia (Org.), XXVI Reunião Anual de Psicologia (P.21). Ribeirão Preto, 1996.

BEVILACQUA, M.C.; FORMIGONI, G. M. P. Audiologia Educacional: uma opção terapêutica para a criança deficiente auditiva. Carapicuíba: Pró-Fono, 1997. 
BEVILACQUA, M.C.; MORET, A. M. Deficiência auditiva: conversando com familiares e profissionais da saúde. São José dos Campos: Pulso; 2005.

BOOTHROYD.A. Hearing impairment in young children. New Jersey, Prentice Hall Englew Word cliffs, 1982.

BRITO, A. M. W.; DESSEN, M. A. Crianças surdas e suas famílias: um panorama geral. Psicol. Reflex. Crit. Vol.12, n.2. Porto Alegre, 1999.

BROWN, C. Os pais são pessoas antes de tudo. In: BUSCAGLIA, L; Os deficientes e seus pais. $3^{\text {a }}$ ed. Rio de Janeiro: Record, 1997.

BEVILACQUA. Maria Cecília. Estudo longitudinal da compreensão verbal de crianças usuárias de implante coclear Ver. CEFAC. 2010. Mar-Abr: 12 (2): 210-215.

BUSCAGLIA, L. F. Os Deficientes e seus pais. $3^{\text {a }}$ Ed. Rio de Janeiro: Record, 1997.

CICCONE, M. M. C. Comunicação total. Rio de Janeiro: Cultura Médica, 1990.

COLE, E. B. Listening and talking: a guide to promoting spoken language in Young hearning-inpaired chidren. Ohio: University of Cincinnati, 1992.

DESSEN, M.A. . Efeitos do nascimento de uma criança no comportamento e nas relações entre o primogênito e os genitores. 1992. Tese (Doutorado em Psicologia). Universidade de São Paulo, SP.

HARRISON, K. M. P. A surdez na Família: uma analise de depoimentos de pais e mães, São Paulo, 1994. Dissertação (Mestrado em Fonoaudiologia). Pontifícia Universidade Católica de São Paulo.

HOLZHEIM, D. C. P. M.; LEVY, C. C. A. C.; PATITUCCI, S. P. R.; GIORGI, S.B.; Família e Fonoaudiologia: o Aprendizado da Escuta. In: LOPES FILHO, O. Tratado de Fonoaudiologia. São Paulo: Ed. Roca, 1997. 
JESUS. Lisiane Nunes. Inclusão do Deficiente Auditivo: Alicerce: família, escola e sociedade. Rio de Janeiro: E- papers, 2009, p.17.

LACERDA, A.P. de: Audiologia Clinica. Rio de Janeiro, Editora Guanabara, 1976.

LAFON, J.C. A deficiência auditiva na criança: deficiência e readaptações. São Paulo: Manole, 1989.

LEIBOVIC, Z. A família e a criança surda; In: CICCONE, M. Comunicação total: A pessoa Surda. Rio de Janeiro: Cultura Médica, 1996.

LEWIS, D. R. RACA, R. BEVILACQUA, M. C. Identificação precoce da deficiência auditiva Revista Distúrbios da Comunicação, 2(3/4), 133-142, Jul/Dez, 1987.

LUTERMAN, D. Deafness in the family. USA: Litlle, Brown and Company, 1987.

LUTERMAN, D. M. Counseling parents of hearing-impaired children. USA, Little e Brown, 1979.

LUTERMAN, D. M.; ROSS, M. When your child is deaf: a guide for parents. Parkton: York Press, 1991.

MAINARDI, Roberta., PESSOTTO, Rosana Beatriz Manfio. Escola e Família: Uma imprescindível 1. Westphalen/RS. 2008. Dissertação (Psicopedagogia em Debate. Série Pesquisa em Ciências Humanas), Universidade Regional Integrada do Alto Uruguai e das Missões. Campus Frederico Westphalen

MINISTÉRIO DA EDUCAÇÃO. Secretaria de Educação Especial. Educação Especial: Deficiência Auditiva. Brasília: MEC/SEEEP, 1994.

MOSS, M.A. (1965). Methodological issues in studying mother-infant interaction. American Journal of Orthopsychiatry, 35, 482-486. 
NAKAMURA, H.Y. LIMA, M.C.M.P. GONÇALVES, V.M.G. Ambulatório de neuropscodiagnóstico da surdez: papel da Equipe Interdisciplinar. IN: LACERDA, C.B.F, NAKAMURA, H. LIAM, M.C. Fonoaudióloga: Surdez e Abordagem Bilíngüe. São Paulo: Plexus, 2000.

NORTHERN, J.L. DOWNS, M.P. Audição em crianças. $3^{a}$ ed. São Paulo: Manole, 1984.

NUNES, B. El niño sordo y su familia: aportes desde la psicología clínica. Buenos Aires: Troquel, 1991.

RAMOS BD, FUKUDAY \& FRANCHE GLS. Electrococleography in children study of 2.336 Cases. Acta AWHO 11:90 - 93, 1992.

ROBSON, K.S. (1967). The role of eye-eye contact in maternal-infant attachment. Journal of Child Psychology and Psychiatry, 8, 13-25.

ROSSI T. L. F. Audição e Fala: Investigando o Corpo Humano. São Paulo: Ática, 1996.

TAVARES, M. Os efeitos dos diagnósticos nos pais da criança surda: uma análise discursiva. São Paulo, 2001. Dissertação (Mestrado em Fonoaudiologia) Pontifícia Universidade Católica de São Paulo.

MAINARDI, Roberta., PESSOTTO, Rosana Beatriz Manfio. Escola e Família: Uma imprescindível 1. Westphalen/RS. 2008. Dissertação (Psicopedagogia em Debate. Série Pesquisa em Ciências Humanas), Universidade Regional Integrada do Alto Uruguai e das Missões. Campus Frederico Westphalen 


\begin{abstract}
APÊNDICES
A pesquisa de campo é embasada exclusivamente em relatos de mães que possuem filhos com deficiência auditiva.

Através de 3 questões:

- Que idade tinha seu filho quando foi descoberta à surdez?

- Como foi descoberta e quem suspeitou que o seu filho não ouvia?

- Qual foi a reação inicial da descoberta da surdez nos pais?
\end{abstract}




\begin{abstract}
ANEXOS
Universidade de Brasília - UnB

Instituto de Psicologia - IP

Departamento de Psicologia Escolar e do Desenvolvimento - PED

Curso de Especialização em Desenvolvimento Humano, Educação e Inclusão Escolar
\end{abstract}

\title{
TERMO DE CONSENTIMENTO LIVRE E ESCLARECIDO
}

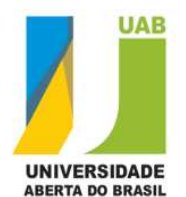

Senhores Professores,

Sou orientando do Curso de Especialização em Desenvolvimento Humano, Educação e Inclusão Escolar, realizado pelo Instituto de Psicologia por meio da Universidade Aberta do Brasil- Universidade de Brasília (UAB-UnB) e estou realizando um estudo sobre O IMPACTO DA DEFICIÊNCIA AUDITIVA

SOBRE A FAMíLIA. Este estudo poderá fornecer às instituições de ensino subsídios para o planejamento de atividades com vistas à promoção de condições favoráveis ao pleno desenvolvimento dos alunos em contextos inclusivos e, ainda, favorecer o processo de formação continuada dos professores nesse contexto de ensino.

Constam da pesquisa entrevista com mães que tem experiência com filho surdo e como objetivo conhecer as reações e sentimentos de mães ouvintes diante do diagnóstico de surdez do filho.

Esclareço que a participação no estudo é voluntária. Você poderá deixar a pesquisa a qualquer momento que desejar e isso não acarretará qualquer prejuízo a você. Asseguro-lhe que sua identificação não será divulgada em hipótese alguma e que os dados obtidos serão mantidos em total sigilo, sendo analisados coletivamente.

Caso tenha alguma dúvida sobre o estudo, o(a) senhor(a) poderá me contatar pelo telefone (15) 32713061 ou (15) 3271-8245 ou no endereço eletrônico carminha.contivaz@bol.com.br. Se tiver interesse em conhecer os resultados desta pesquisa, por favor, indique um e-mail de contato.

Agradeço antecipadamente sua atenção e colaboração.

\section{Respeitosamente,}

Maria do Carmo Conti Vaz de Oliveira

Educação Inclusiva pólo UAB - UnB - Itapetininga/SP

Concorda em participar do estudo? ( ) Sim ( ) Não

Nome:

Assinatura:

E-mail (opcional):

OBSERVAÇÃO:

O Termo de Consentimento Livre e Esclarecimento não foram necessários por se tratar de uma Escola Estadual Pública a qual conheço a equipe gestora, professores e comunidade escolar. 